\title{
The NCSBN Medical Marijuana Nursing Guidelines Committee
}

Cathy Borris-Hale, MHA, RN

Nurse Specialist II - Discipline

Board of Nursing

Health Regulation and Licensing Administration

Department of Health

District of Columbia

Maureen Cahill, MSN, APN-CNS, RN

Senior Policy Advisor, Nursing Regulation

National Council of State Boards of Nursing

Rene Cronquist, JD, RN, Chair

Director for Practice and Policy

Minnesota Board of Nursing

Holly Fischer, JD

Chief Legal Counsel

State of Ohio Board of Nursing

Kent Gowen, MA

Policy Coordinator, Nursing Regulation

National Council of State Boards of Nursing
Diana Heywood, MN, RN

Practice and Standards Consultant

College of Registered Nurses of Manitoba

Manitoba

James (Dusty) Johnston, JD

General Counsel

Texas Board of Nursing

Kathleen Russell, JD, MN, RN

Senior Policy Advisor, Nursing Regulation

National Council of State Boards of Nursing

Valerie Smith, MS, RN, FRE

Director-at-Large, Associate Director

Arizona State Board of Nursing

Sherrie Sutton-Johnson, MSN, RN

Director of Nursing Education

Florida Board of Nursing 